\title{
DEF Induction in the Laboratory and Effect of Silica Fume on the Expansions of Mortars
}

\author{
S. OLIVEIRA ${ }^{1,2}$, A. M. OLIVEIRA ${ }^{2}$, N. P. HASPARYK ${ }^{1 *}$ \\ ${ }^{1}$ ELETROBRAS Furnas, Rodovia BR 153, s/n - Zona Rural, Aparecida de Goiânia - GO, 74923-650, Brazil. \\ nicole@furnas.com.br* \\ ${ }^{2}$ GEDur - Durability Study Group, Laboratory of Technological Innovation in Civil Construction - LABITECC, \\ PPG-GECON, Civil and Environmental Engineering School, Federal University of Goiás (Universidade Federal de \\ Goiás - UFG), 74.605-220. Praça Universitária, Goiânia - GO, Brazil, sol.adm2018@gmail.com, \\ andriellimorais@ufg.br
}

\begin{abstract}
Delayed ettringite formation (DEF) is a pathological phenomenon responsible for several types of damage to concrete elements and structures. The lack of test methods, protocols and preventive standards based on concrete mixes and inhibitor admixtures are concerned. This paper presents the results from an experimental program performed in the laboratory with a procedure developed for inducing DEF. An initial thermal cycle was conducted accompanied by the exposition of mortars to a specific environment in order to monitor expansions over time. Mortars were cast with silica fume as partial cement replacement at ratios of $0 \%, 4 \%, 8 \%$ and $12 \%$, by volume. The adopted procedure was able of promoting DEF and the silica fume presented potential to mitigate DEF expansions, even though some ettringite crystals was produced in the cement matrix by microstructural analyses at six months.
\end{abstract}

Keywords: DEF; thermal cycle; expansion; silica fume; mitigation.

\section{RESUMO}

A formação de etringita tardia (DEF) é um fenômeno patológico responsável por vários tipos de danos em elementos e estruturas de concreto. A falta de métodos de ensaio, protocolos e normas preventivas baseadas em misturas de concreto e adições inibidoras é preocupante. Este artigo apresenta os resultados de um programa experimental realizado em laboratório com um procedimento adotado para a indução da DEF. Foi realizado um ciclo térmico inicial acompanhado pela exposição de argamassas a um ambiente específico com o objetivo de monitorar as suas expansões ao longo do tempo. As argamassas foram moldadas com sílica ativa em substituição parcial do cimento, em volume, nos teores de $0 \%, 4 \%, 8 \%$ e $12 \%$. O procedimento adotado foi capaz de promover a DEF e as argamassas com sílica ativa apresentaram potencial para mitigar as expansões, apesar de alguns cristais de etringita serem detectados na matriz cimentícia por análises microestruturais aos seis meses.

Palavras-chave: DEF; ciclo térmico; expansão; sílica ativa; mitigação.

\section{RESUMEN}


La formación de la etringita tardía (DEF) es un fenómeno patológico responsable por diversos tipos de daños en los elementos y las estructuras de hormigón. La carencia de los métodos de ensayos, protocolos y normas preventivas basados en la mezcla de hormigón y adiciones inhibitorias es una preocupación. Este artículo presenta los resultados de un programa experimental llevado a cabo en el laboratorio con un procedimiento adoptado para la inducción de DEF. Se realizó un ciclo térmico inicial acompañado de la exposición de los morteros a un entorno específico para controlar su expansión en el tiempo. Los morteros fueron moldeados con sílice activa en substitución parcial del cemento, en volumen, en los contenidos de $0 \%, 4 \%, 8 \%$ y $12 \%$. El procedimiento adoptado logró promover la DEF y los morteros con sílice activa mostraron potencial para mitigar las expansiones, aunque se detectaron algunos cristales de etringita en la matriz de cementación por análisis microestructurales a los seis meses.

Palabras llave: DEF; ciclo térmico; expansión; sílice activa; mitigación.

\section{INTRODUCTION}

Delayed ettringite formation (DEF) is a complex phenomenon of chemical reactions that involves sulphated phases during cement hydration with the water from the concrete and the environment surrounding the structure (Schovanz et al., 2021). This phenomenon can affect various types of elements and structures such as foundations (Han et al., 2019), dams (Blanco et al., 2019), and bridges. As a result of DEF, concrete durability is affected due to several problems, such as expansions of concrete elements, the incidence of cracking and decrease of the mechanical properties with reductions in the service life.

Several studies report the dependence on temperature, duration and type of cure, and cement supplies (Kchakech et al., 2016; Yammine et al., 2020; Gu et al., 2020; Jebli et al., 2021). In addition, the effects of chemical compounds on cement hydration, especially calcium sulfate, the physico-chemical and mineralogic properties of the clinker, chemical admixtures, water/binder ratio and hydration age have also been studied, with the main results published in the literature (Bronholo, 2020; Andrade Neto et al., 2021; Schovanz et al., 2021).

However, studies are limited about the use of Supplementary Cementitious Materials (SCMs) and of silica fume, in particular, to avoid or to mitigate DEF expansion. Some researchers concluded that the use of finer pozzolan in partial replacement of cement can control or even eliminate DEF expansion (Nguyen et al., 2013; Amine et al., 2017; Zhuang and Sun, 2020).

This paper shows results from an experimental program performed in the laboratory with a procedure to induce DEF in mortars with partial replacement of cement by silica fume at $0 \%, 4 \%$, $8 \%$ and $12 \%$, by volume. Initially, the tests involved the exposure of mortars to a specific thermal cycle and the monitoring of expansion over time.

The relevance of this paper is to improve understanding about DEF and the role of silica fume, in addition to contributing to the durability and good performance of concrete structures.

\section{EXPERIMENTAL PROGRAM}

The study was performed in cement mortars with and without silica fume. Reference mortars were cast with a high-early strength Portland cement (Brazilian CP V type, similar to ASTM CP III type), with no admixture. Mortars containing silica fume (SF) were cast with contents of 4\%, 
$8 \%$ and $12 \%$ of this pozzolan, by volume replacement of cement. For those mortars, the use of a specific polyfunctional chemical admixture was required in other to adjust their rheological properties and to promote improvement of its performance. Cylindrical $(50 \mathrm{x} 100 \mathrm{~mm})$ and prismatic $(25 \times 25 \times 285 \mathrm{~mm})$ specimens were prepared for mechanical and expansion tests, respectively.

The mortar mix was 1:2,75: 0,485 by weight. In order to isolate DEF, an ASR innocuous sand was used. This behavior was previously tested by the AMBT - accelerated mortar bar test, according to the Brazilian standard (NBR 15577, Part 4, 2018). The sand characteristics were: gravity of $2.64 \mathrm{~g} / \mathrm{cm}^{3}$; powdered material of $5.45 \%$; absorption equal to $0.20 \%$ and expansion at 30 days equal to $0 \%$.

After casting, the mortars were subjected to conventional curing for up to 4 hours to maintain the initial setting of the cement (pre-curing period). After this stage, a thermal cycle was adopted to promote DEF. To this end, the cast specimens were placed in a chamber under water and heated to up to $80^{\circ} \mathrm{C}$ at a heating rate of $10^{\circ} \mathrm{C} / \mathrm{h}$. Furthermore, specimens were maintained at this temperature for 12 hours and, subsequently, the mortars were cooled to $38^{\circ} \mathrm{C}$ at the same rate and kept at this exposure condition for up to 6 months. The adopted procedure was based on the one presented by Schovanz (2019) and Hasparyk et al. (2020), with the temperature being decreased from $85^{\circ} \mathrm{C}$ to $80^{\circ} \mathrm{C}$, and applying it to mortars instead of concretes.

Expansions of the prismatic mortar bars were monitored and the water $\mathrm{pH}$ of the chamber was also monitored over time. Moreover, some additional analyses were performed, such as compressive strength of mortars with conventional curing, visual and microstructural analyses by Scanning electron microscope (SEM) and energy dispersive X-ray spectroscopy (EDS).

The main characteristics of the cement and silica fume are shown in Table 1.

Table 1 -CP V-ARI and Silica fume main characteristics (\%).

\begin{tabular}{|c|c|c|c|c|c|c|c|c|}
\hline $\mathrm{SiO}_{2}$ & $\mathrm{Al}_{2} \mathrm{O}_{3}$ & $\mathrm{Fe}_{2} \mathrm{O}_{3}$ & $\mathrm{CaO}$ & MgO & $\mathrm{Na}_{2} \mathrm{Oeq}$ & $\mathrm{SO}_{3}$ & LI & IR \\
\hline \multicolumn{9}{|c|}{ Components from CP V Cement (\%) } \\
\hline 18.74 & 4.19 & 2.79 & 62.49 & 1 & 0.73 & 3.29 & 4.22 & 0.73 \\
\hline \multicolumn{9}{|c|}{ Components from Silica Fume (\%) } \\
\hline 95.21 & 0.22 & 0.18 & 0.45 & 0.47 & 0.66 & 0 & 2.46 & - \\
\hline \multicolumn{9}{|c|}{$\mathrm{Na}_{2} \mathrm{Oeq}=0.658 \mathrm{~K}_{2} \mathrm{O}+\mathrm{Na}_{2} \mathrm{O}$; Cement and silica fume gravity: $3.09 \mathrm{~g} / \mathrm{cm}^{3} / 2.25 \mathrm{~g} / \mathrm{cm}^{3}$, respectively; Blaine } \\
\hline
\end{tabular}

Figure 1 shows a micrograph of the silica fume used in the experiments. Spherical particles vary from $5 \mathrm{~nm}$ to $250 \mathrm{~nm}$. Figure 2 shows the diffractogram from XRD exhibiting a main amorphous band of this pozzolan and small peaks from quartz and moissanite. 


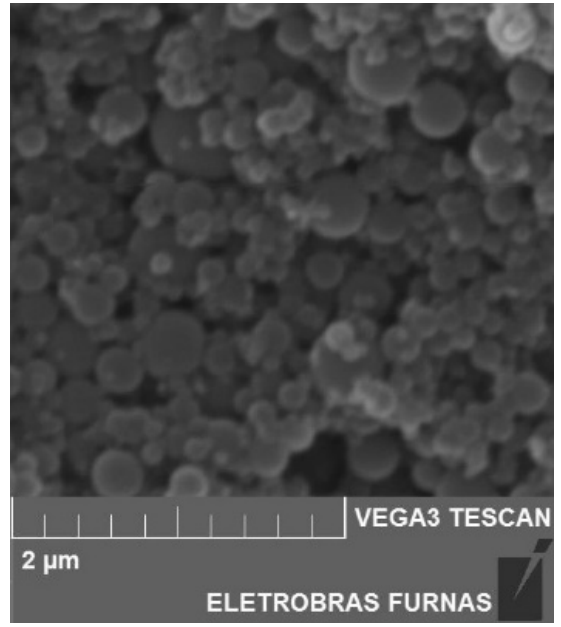

Figure $1-$ SEM of SF. Source: Furnas

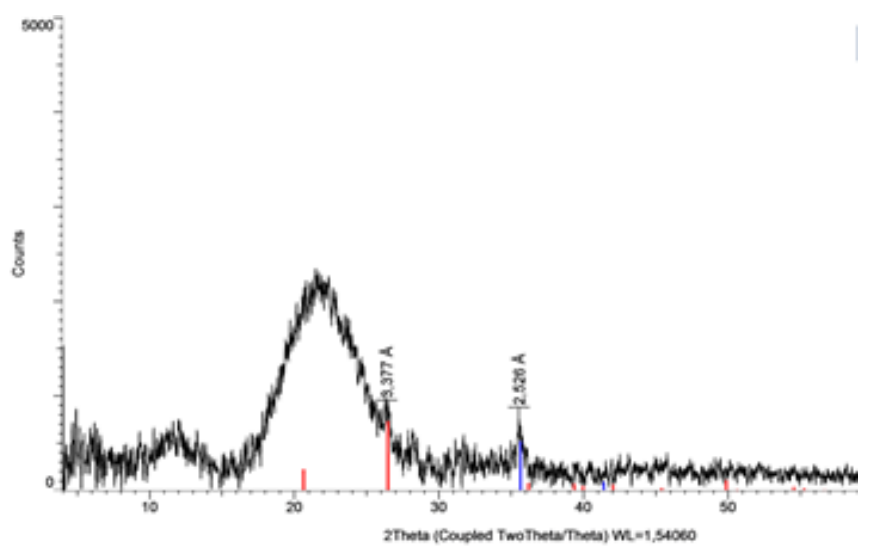

Figure $2-\mathrm{XRD}$ of SF.

Source: Furnas

\section{RESULTS}

\subsection{EXPANSIONS}

In Figure 3, the results of the mortar expansions are presented over time until the age of 6 months. The nomenclature adopted were: reference sample (REF) and samples with 4\% (SF4), $8 \%$ (SF8) and 12\% (SF12) of silica fume replacing the cement (by volume).

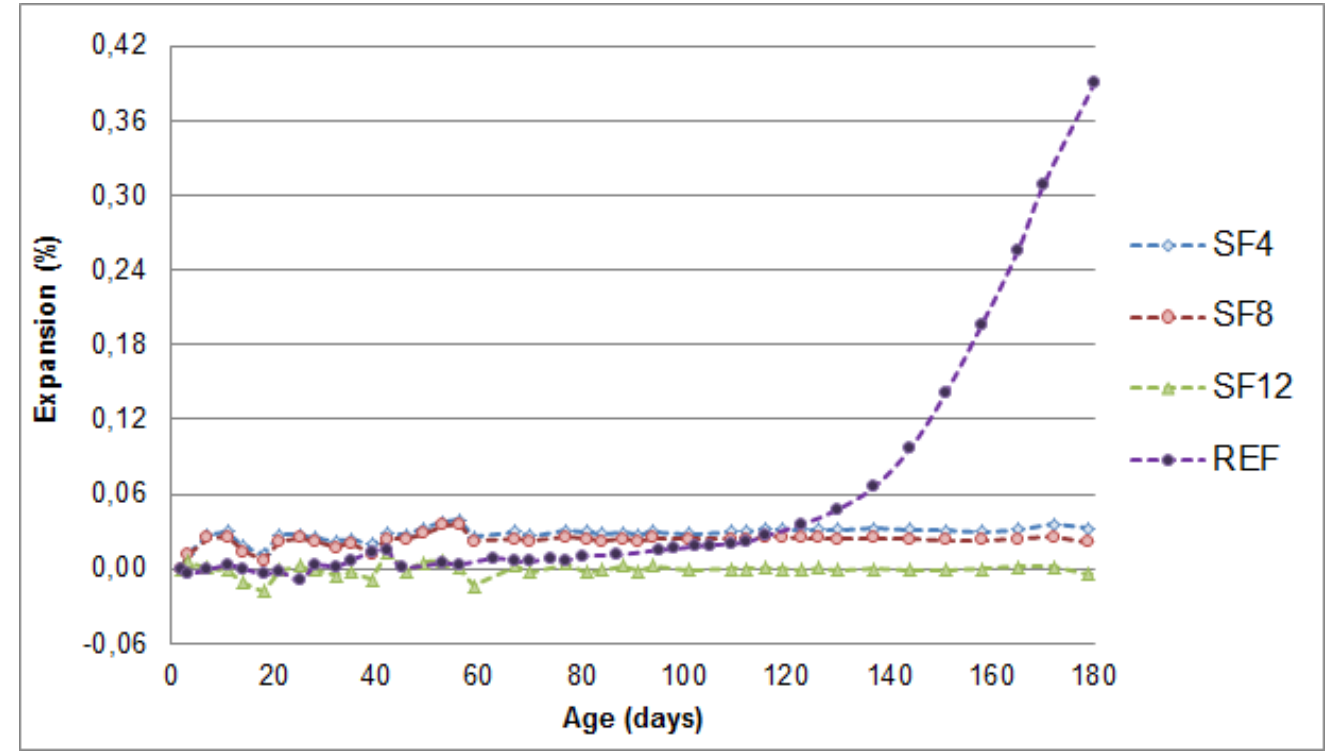

Figure 3 - Expansions (in average) of mortars over time.

As a result of, readings up to 56 days showed the following expansion averages: REF $(0.00 \%)$, SF4 (0.04\%), SF8 (0.04\%) and SF12 (0.00\%). After 100 days, the samples with silica fume (at the 3 levels) remained stable, but in the reference sample the expansion process was abruptly activated. At the age of 180 days, the reference sample's expansion reached an expressive value 
of about $0,40 \%$, with an important increase of expansions over time. This behavior did not occur for the other conditions tested with silica fume. The results are in agreement with Bronholo (2020). This researcher used CPV type Portland cement and reported an expansion growth trend after 240 days in the reference condition.

Figure 4 shows the performance of mortars with silica fume in relation to the potential for reducing expansions over time. The results were promising, and the following reductions were observed at 4 months for the mortars SF4, SF8 and SF12: approximately 10\%, 30\% and 100\%, respectively. The SF12 sample showed an important result at 4 months of study, with null expansion. At 6 months, the efficiency (reduction in expansions) achieved values above about $90 \%$.

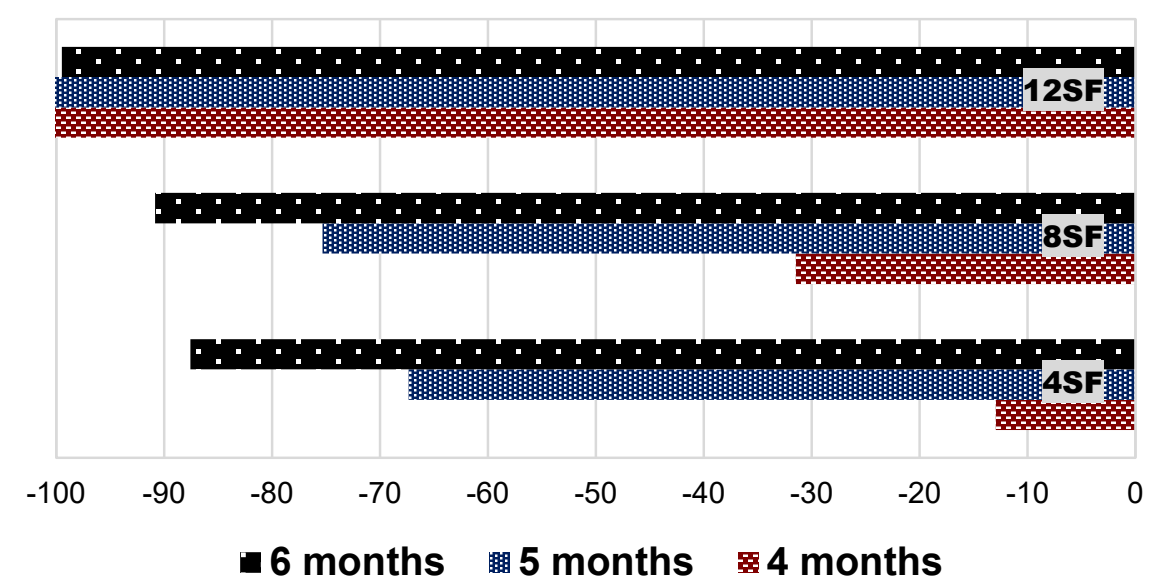

Figure 4 - Reduction in DEF expansions with SF.

Some studies with mortar have used mineral admixtures in mass substitution of a part of the cement to mitigate DEF. Nguyen et al. (2019) used metakaolin at the contents of $10 \%, 20 \%$ and $30 \%$, resulting in almost null expansion (about 0.005\%) for the two higher contents of this pozzolan at the age of 650 days. The mortar behavior with $10 \%$ of metakaolin merely postponed the beginning of expansions; an activation occurred after one year, with high value at 650 days $(0.5 \%)$, thus, this content was not efficient in reducing expansions over time. In another study, Leklou et al. (2016) evaluated the efficiency of the use of fly ash type F at the same contents and period of study, and the results were similar.

Deboucha et al. (2018) had also obtained good results for DEF inhibition using blast furnace slag in partial substitution to cement $(10 \%, 20 \%$ and $40 \%$, by weight), with some delay in the start of expansions. However, they were not enough for DEF mitigation. On the other hand, $40 \%$ of slag was effective over time, and up to 750 days. This behavior was similar to the one obtained and presented in this study with SF8 and SF12.

Figure 5 shows the compressive strength results at the age of 28 days for the studied reference samples. For this test, the specimens were cast and stored according to the mortar bars, submerged in water at the temperature of $38^{\circ} \mathrm{C}$. 


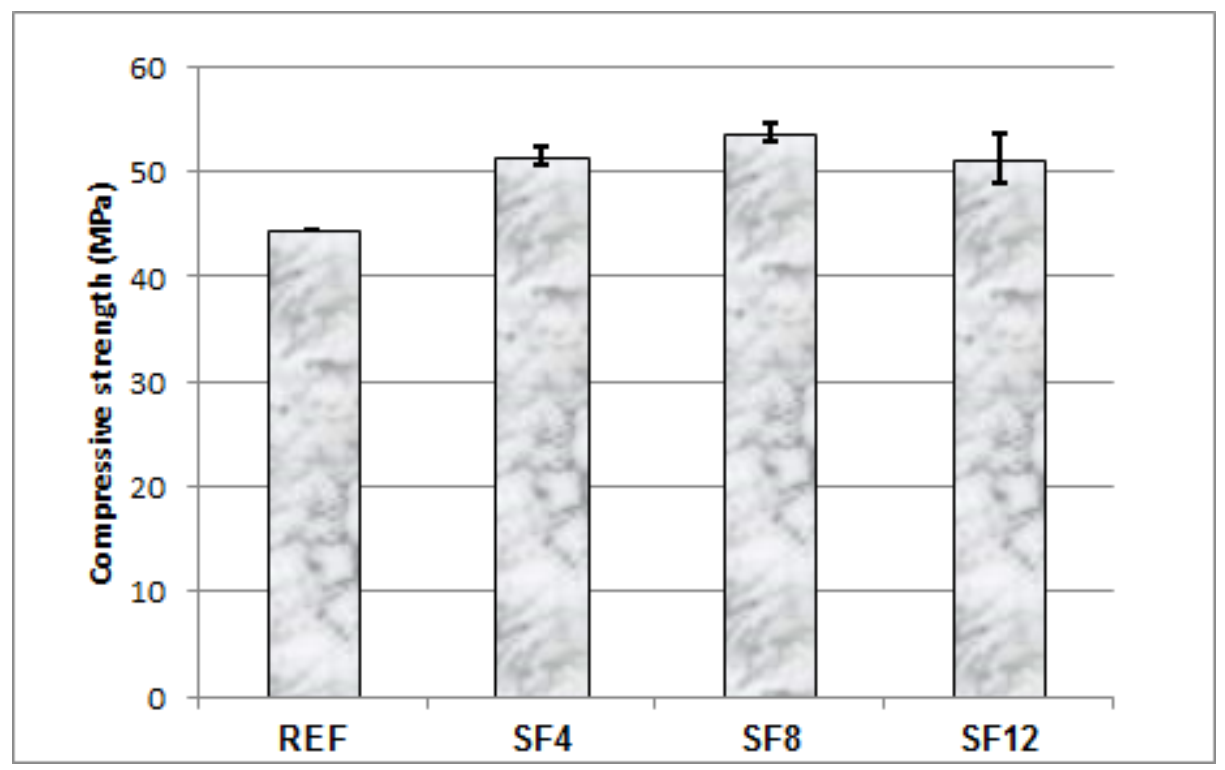

Figure 5 - Compressive strength at the age of 28 days.

The variance analysis (ANOVA) was performed to assess whether the differences were statistically significant, as can be seen in Table 2. The confidence level considered for ANOVA was $95 \%$. There were significant differences in the REF mortar compared to the mortars with silica fume $(\mathrm{F}>\mathrm{Fc})$. Among all tested samples, the content of $8 \%$ of silica fume have indicated the best mechanical performance, especially in comparison to REF. According to the Tukey homogeneity test, the samples containing silica fume are similar (4, 8 and 12\%).

Table 2 - ANOVA of the compressive strength results at the age of 28 days.

\begin{tabular}{ccccccc}
\hline ANOVA & SQ & gl & MQ & F & P & Fc \\
\hline Between groups & 144.7133 & 3 & 48.237778 & 23.11715 & 0.00027 & 4.066181 \\
Within groups & 16.69333 & 8 & 2.0866667 & & & \\
Total & 161.4067 & 11 & & & & \\
\hline
\end{tabular}

SQ-Sum of squares; gl-Degree of freedom; MQ-Medium squares; P-P-value; F-CriticalF

These results are in agreement with Hamid et al. (2018), who obtained similar behavior with the use of binary mixtures, using $15 \%$ metakaolin or silica fume on mass replacement of a part of the cement. They observed an increase of $20 \%$ on compressive strength at 28 days, as expected by this type of pozzolans.

The $\mathrm{pH}$ values of the immersion water of specimens over time are shown the Figure 6 . The initial $\mathrm{pH}$ was about 6 , but at the age of 4 months, $\mathrm{pH}$ achieved value around 11 ( $83 \%$ increase). Not only, after 5 months, $\mathrm{pH}$ measured increased for approximately 9 , and at the age of 6 months the measured $\mathrm{pH}$ value was close to 10 . 


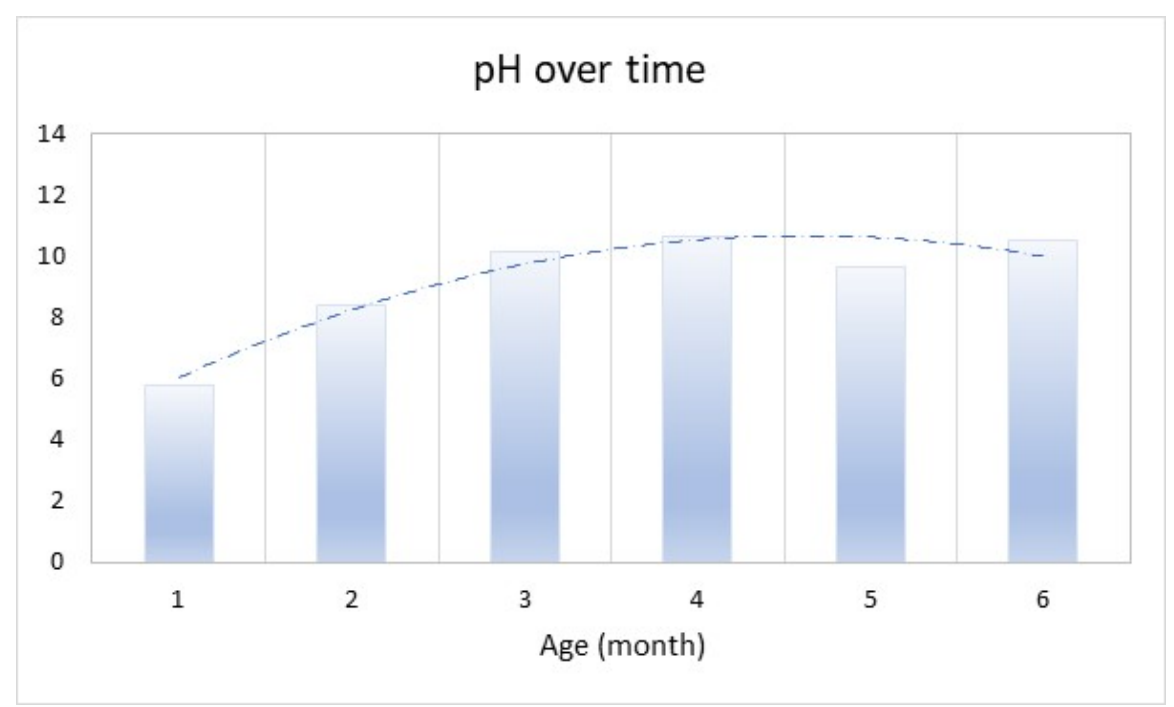

Figure $6-\mathrm{pH}$ measurements over time.

The storage environment is favorable to the occurrence of leaching (release of alkaline hydroxides and calcium hydroxide), causing precipitation of carbonates in the water, which may explain the increase in $\mathrm{pH}$ of the immersion water.

In Pichelin et al. (2020), the concentration of alkaline equivalent of the specimen storage water (submitted to DEF), which was $0.6 \mathrm{mmol} / 1$ changed to $50 \mathrm{mmol} / 1$ after 200 days of study. This change was explained by the alkali leaching of the specimens.

Figure 7 shows photos taken during the internal visual inspection of the mortars being prepared for scanning electron microscopy analysis. The main symptoms observed were the white depositions in the voids, which indicates the formation of ettringite. It is worth noting that in the reference sample the pores are larger, with more visible white formations (Figure 7a). On the order hand, samples with silica fume presented smaller voids and proportional reduction with the increase of silica fume contents. In the SF12 sample, minor white spots could be seen with less material deposited. 


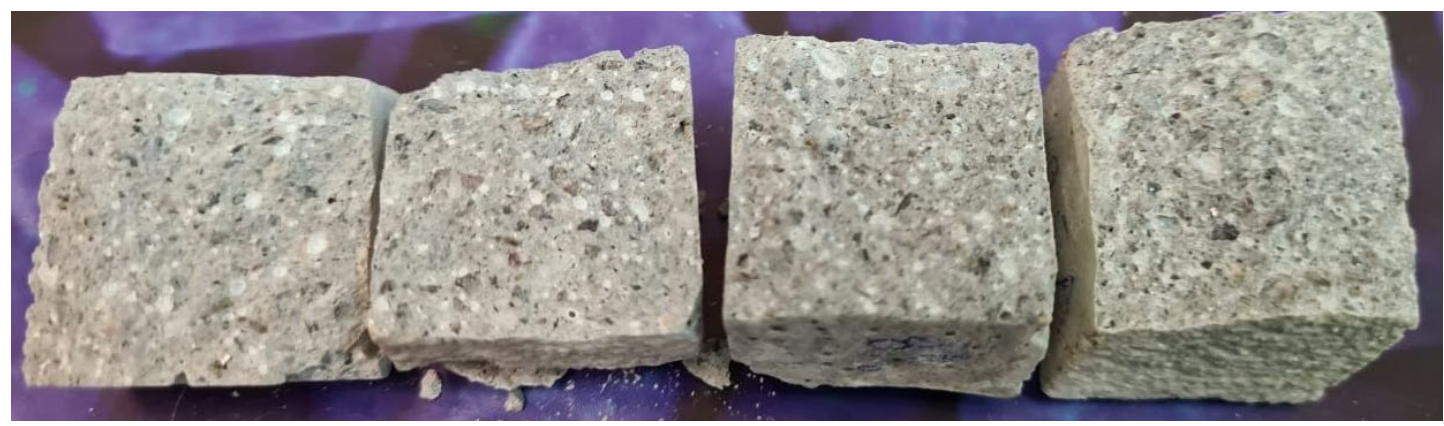

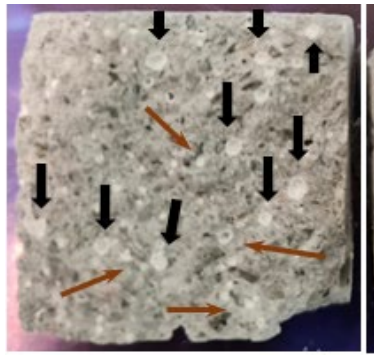

a)

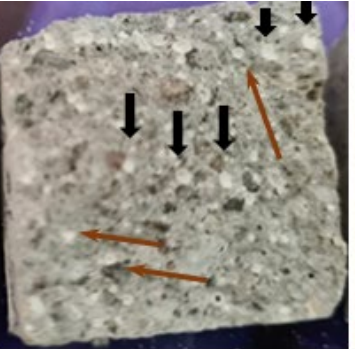

b)

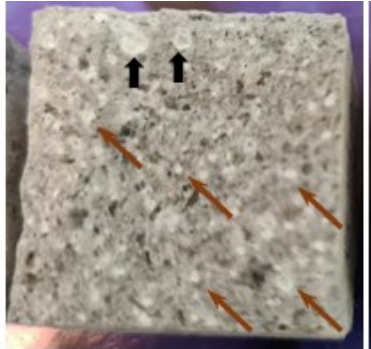

c)

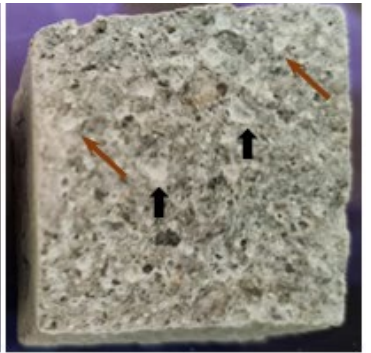

d)

Figure 7 - Internal portion of the mortar bars: a) reference; b) SF4; c) SF8 and d) SF12.

The micrographs (Figures 8 and 10) show the characteristics observed in the SEM. Ettringite can be seen occupying several localities, such as in the voids and also in the cement matrix. All products were confirmed by EDS, as shown in Figure 9, as an example. Differences could be observed in the REF massive neoformation and SF sample: for SA12 mortar, the formation of ettringite crystals was less densified. However, there were formations of secondary ettringite in other localities, causing microcracking in both, REF and SF12 mortars (Figure 10).

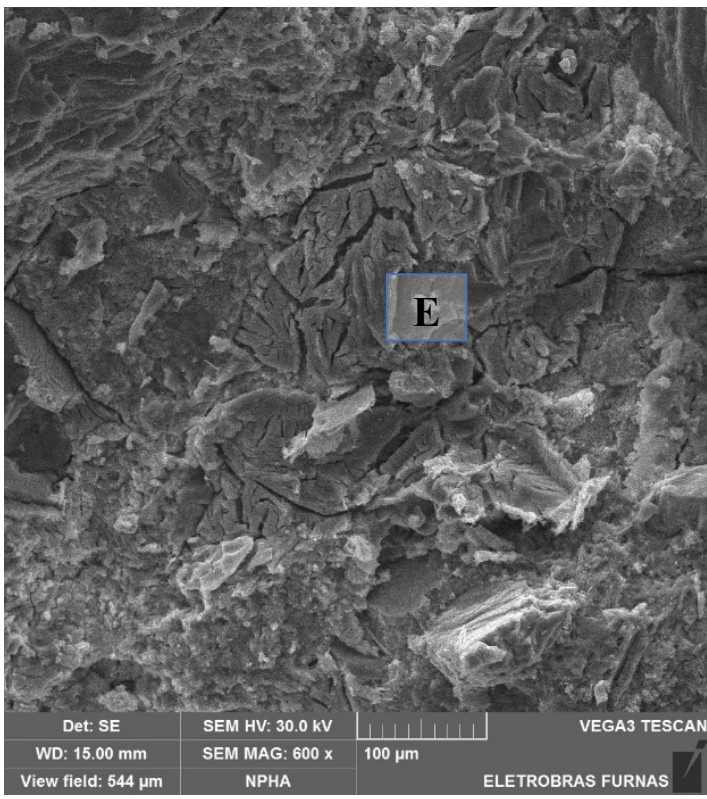

a) Ref. mortar: cement paste completely altered with massive secondary ettringite. (E).

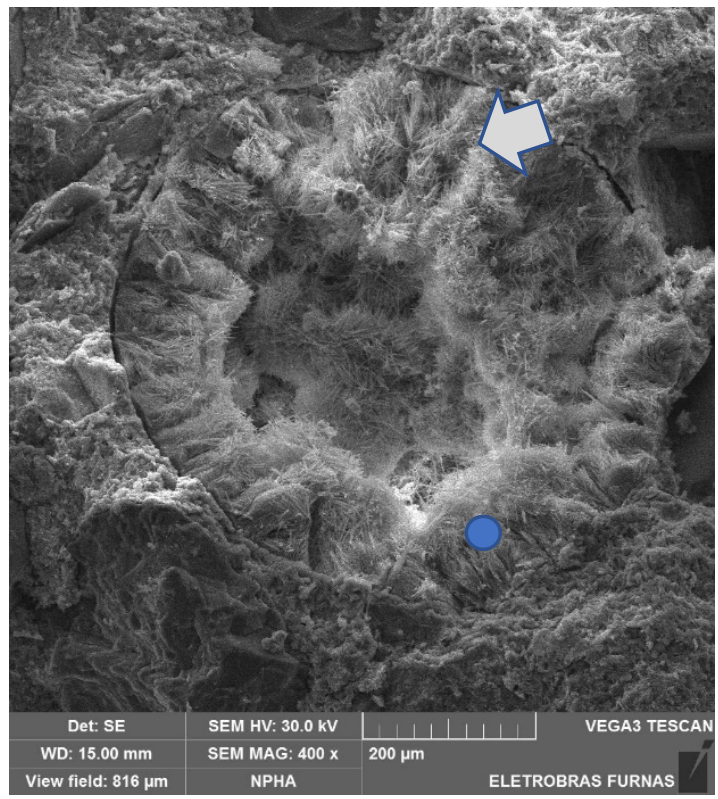

b) Ref. mortar: Ettringite crystals filling a void.

Figure $8-\mathrm{MEV}$ of the reference mortar. 


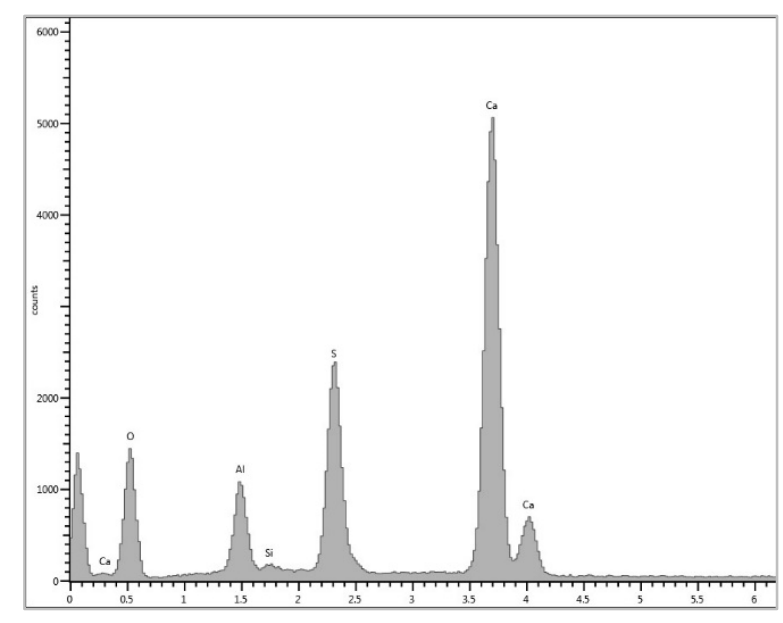

Figure 9 - EDS spectrum of ettringite from the blue point in Fig. 8 b).

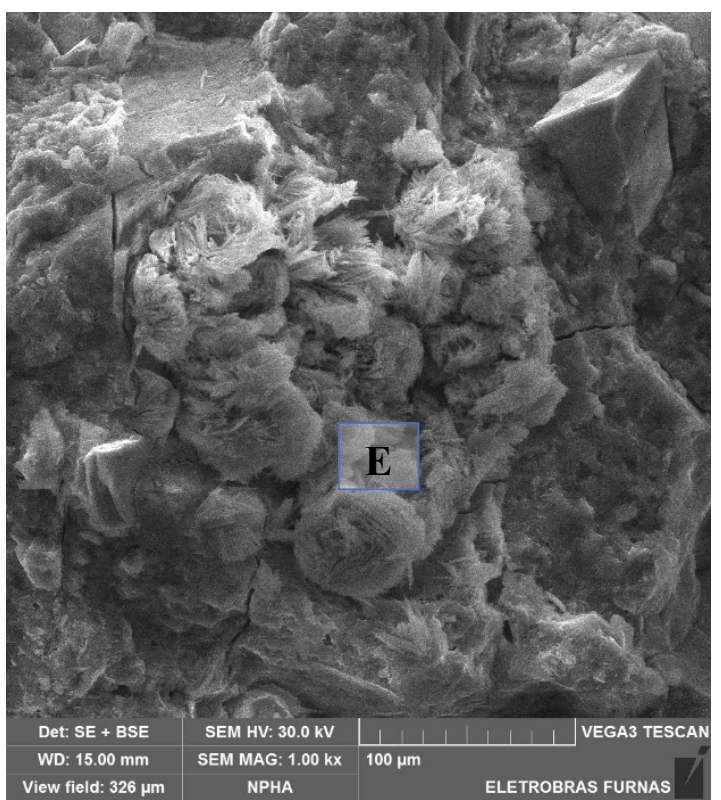

a) $12 \mathrm{SF}$ mortar: some agglomerations of ettringite crystals in the cement matrix and microcracking.

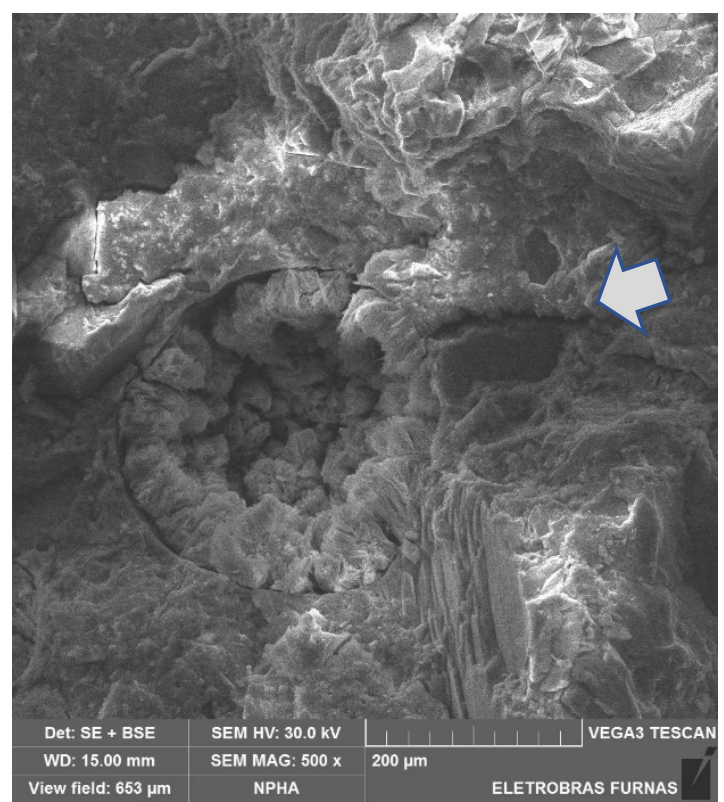

b) 12SF mortar: deposition of several ettringite agglomerations in a void and radial cracking.

Figure $10-$ MEV of the mortar with $12 \%$ of SF.

\section{CONCLUSIONS}

The results from this research indicate the potential of silica fume as a preventive measure to mitigate DEF expansions. According to the mortar bar tests, the expansion in the reference mortar was only activated after about 4 months. Meanwhile, mortars containing silica fume did not expand. At six months, the expansion level for the reference mortar was very expressive (about $0,40 \%$ ), while the expansion of the silica fume mortars remained very low (less than $0,02 \%)$.

Based on the expansive behaviors, a proper content of silica fume with the best performance could be selected according also to the mechanical property of the mortars. However, from the microstructural perspective several ettringite formations were detected in the cement matrix of SF12, indicating a continuous and slow DEF process over time. 
Additionally, this feature brings some alert about prompt responses taking into account mortar tests and reduced time of investigations. A continuous study based on concrete specimens is necessary. The DEF has been responsible for a lot of damage to concrete structures, and the correct design and technological control are necessary to guarantee the performance and durability of structures in relation to these expansive reactions. Care must be taken regarding the maximum temperature of thermal curing, limiting it to up to $60^{\circ} \mathrm{C}$. In the case of the high temperature risks from the heat of cement hydration, a proper cooling system must be used to avoid future problems.

\section{ACKNOWLEDGMENTS}

This work had financial and infrastructure support from Furnas Centrais Elétricas S.A./ANEEL, P\&D 0394-1504-2015. The authors would like to acknowledge the support of the Eletrobras Furnas company for financing the research and also of the technicians who contributed to this study.

\section{REFERENCES}

ABNT Associação Brasileira de Normas Técnicas. (2018). NBR 15577-4: Agregados. Reatividade álcali-agregado . Parte 4: Determinação da expansão em barras de argamassa pelo método acelerado. Rio de Janeiro.

Amine, Y., Leklou, N. and Amiri, O. (2017), Effect of supplementary cementitious materials (SCM) on delayed ettringite formation in heat-cured concretes. Energy Procedia. 139: 565-570.

Andrade Neto, J. S., Torre, A. G. and Kirchheim, A. P. (2021), Effects of sulfates on the hydration of Portland cement - A review. Construction and Building Materials. 279: 1-17.

Blanco, A., Pardo-Bosch, F., Cavalaro, S. and Aguado, A. (2019), Lessons Learned About the Diagnosis of Pathologies in Concrete Dams: 30 Years of Research and Practice. Construction and Building Materials. 197: 356-368. doi: 10.1016/j.conbuildmat.2018.11.143.

Bronholo, J. (2020), "Estudo do ataque individual e misto de DEF e RAA e de seus efeitos deletérios nas propriedades físico-químicas e mecânicas de concretos e argamassas de cimento portland Pozolânico e de alta resistência", Master Thesis, Instituto de Engenharia do Paraná, p. 216 (in Portuguese).

Deboucha, W., Leklou, N. and Khelidj, A. (2018), Blast Furnace Slag Addition Effects on Delayed Ettringite Formation in Heat-cured Mortars. KSCE Journal of Civil Engineering. 1-7. Doi: 10.1007/s12205-017-0642-6

Gu, Y., Metalssi, O. O., Martin R. P., Chong, T. F. and Dangla, P. (2020), Locating ettringite due to DEF at the pore scale of cement paste by heat-based dissolution tests. HAL archives-ouvertes. 258: 1-19.

Hamid, H., Chorzepa, M. G., Sullivan, M., Durham, S. and Kim, S. S. (2018), Novelties in Material Development for Massive Concrete Structures: Reduction in Heat of Hydration Observed in Ternary Replacement Mixtures. Infrastructures. 3(8):1-20. 
Hasparyk, N.P., Schovanz, D. and Kuperman, S. (2020), Instrução Técnica Furnas no GSTE004R0 - Método de Ensaio para a Avaliação do Potencial de Ocorrência da Etringita Tardia (DEF) em Concreto. Ed. FURNAS.

Jebli, M., Jamin, F., Pelissou, C., Lhopital, E. and El Youssoufi, M.S. (2021), Characterization of the expansion due to the delayed ettringite formation at the cement paste-aggregate interface. Construction and Building Materials. 289: 122979.

Kchakech, B., Martin, R.-P, Omikrine-Metassi, O., Renaud, J.-C., Baron, L. and Toutlemonde, F. (2016), "Effect of Temperature and Curing Duration of Early Heat Treatments on the Risk of Expansion Associated with Delayed Ettringite Formation"' in: Proceedings of the 15th ICAAR International Conference on Alkali-Aggregate Reaction in Concrete, H. Bernardes, and N. P. Hasparyk, ed., São Paulo, Brazil.

Leklou, N., NGUYEN, V. H. and MOUNANGA, P. (2016), The effect of the Partial Cement Substitution with fly ash on delayed ettringite formation in heat-cured mortars. Journal of Civil Engineering. 21: 1359-1366.

Nguyen, V., Leklou, N., Aubert, J.-E. and Mounanga, P. (2013), The Effect of Natural Pozzolan on Delayed Ettringite Formation of the heat-cured mortars. Construction and Building Materials. 48: 479-484. doi: 10.1016/j.conbuildmat.2013.07.016.

Nguyen, V., Leklou, N. and Mounanga, P. (2019), The Effect of Metakaolin on Internal Sulphate Attack of the Heat-Cured Mortars. Romanian Journal of Materials. 49 (1): 51-57.

Pichelin, A., Carcasses, M., Cassagnabere, F., Multon, S. and NAHAS, G. (2020), Sustainability, transfer and containment properties of concrete subject to delayed ettringite formation (DEF). Cement and Concrete Composites. 113: 1-15.

Schovanz, D. (2019), "Estudo da formação da etringita tardia (DEF) em concretos com cimento Portland pozolânico e de alta resistência”, Master Thesis, IMED, p. 163 (in Portuguese).

Schovanz, D., Tiecher, F., Hasparyk, N. P., Kuperman, S. and Lermen, R. T. (2021), Evaluation of Delayed Ettringite Formation through Physical, Mechanical, and Microstructural Assays. ACI Materials Journal. 118: 101-109.

Yammine, A., Leklou, N., Choinska, M., Bignonnet, F. and Mechling, J-M. (2020), DEF damage in heat cured mortars made of recycled concrete sand aggregate. Construction and Building Materials. 252: 119059.

Zhuang, S. and SUN, J. (2020), The feasibility of properly raising temperature for preparing high-volume fly ash or slag steam-cured concrete: An evaluation on DEF, 4-year strength and durability. Construction and Building Materials. 242: 118094. 